\title{
New Technologies and the Impact on Personality Rights in Brazil
}

\section{Novas tecnologias e o impacto nos direitos da personalidade no Brasil}

\author{
Marcelo Negri Soares* \\ Marcos Eduardo Kauffman ** \\ Kuo-Ming Chao* \\ Maktoba Omar Saad
}

\begin{abstract}
As technology continues to evolve at an exponentially increasing pace, it transforms our lives and societies, thus shaping our perceptions of reality with high speed and impacting the relationship between the individual and the society, including businesses and, as a result, the legal system. The young area of law is trying to explore the effects of new technologies in our relationships with it, as well as identify the best use of new technologies to reduce the gap among new technology, new societal behaviors and various legal systems. The purpose of this paper is to examine the current uses of wearable technologies in Brazil and the legal issues emerging from the various uses of these technologies and their impact on personality rights. So, to what extent do the Brazilian users of emerging technologies appreciate the terms and conditions agreed by themselves and their impact on personality rights? The authors used empirical quantitative data from a crosssection of Brazilian users to explore the level of awareness in regards to the terms and conditions associated with the use of emerging technologies and the impact on their personality rights. The authors found that the large majority of these users of technology are unaware of the adverse impact of the agreed terms and conditions on their personality rights. Furthermore, they are also unaware of the basics of how technology operates and therefore are unable to enforce their rights. The research is based on data collected by using only one survey with a sample of 500 students from three universities in three Brazilian States with an age range between 18 and 40 years old. This paper extends the previous research on the impact of emerging technologies on personality rights and demonstrates with empirical data that there is a serious risk of erosion of such rights. Furthermore, this research provides a unique insight into the users of emerging technologies in the emerging Brazilian market and the impact on the Brazilian legal system. ${ }^{1}$
\end{abstract}

Keywords: Disruptive technologies. Wearable technologies. Personality rights. Social innovation. Technology and law. Emerging markets, Brazil.

\section{Resumo}

À medida que a tecnologia continua evoluindo em um ritmo exponencialmente crescente, ela transforma nossas vidas e sociedades, moldando assim nossas percepções da realidade em alta velocidade e impactando o relacionamento entre o indivíduo, a sociedade, incluindo empresas e, como resultado, o sistema jurídico. A área jovem do direito está tentando explorar os efeitos das novas tecnologias em nossos relacionamentos com a lei, bem como busca identificar o melhor uso das novas tecnologias para reduzir a lacuna entre a nova tecnologia, os novos comportamentos sociais e os vários sistemas jurídicos. Então, o objetivo deste artigo é examinar os usos atuais de tecnologias vestíveis no Brasil e as questões legais emergentes dos vários usos dessas tecnologias e seu impacto nos direitos da personalidade. Pergunta-se, como problema de pesquisa, até que ponto os usuários brasileiros de tecnologias emergentes apreciam e entendem os termos e condições acordados por eles mesmos e seu impacto nos direitos da personalidade? Sob o aspecto metodológico, os autores utilizaram dados quantitativos empíricos de uma seção transversal de usuários brasileiros para explorar o nivel de consciência em relação aos termos e condições associados ao uso de tecnologias emergentes e ao impacto

Doutor e Mestre em Direito pela PUC-SP. Pós-doutor Uninove/SP. Professor da Universidade Federal do Rio de Janeiro (Faculdade Nacional de Direito). Professor Permanente do Programa de Ciências Jurídicas - Mestrado e Doutorado da Unicesumar (Maringá-PR). Pesquisador FAPESP, ICETI e NEXT SETI. Rio de Janeiro - RJ - Brasil. E-mail: negri@negrisoares.com.br.

* Law Professor, Intellectual Property. Doctor in Business and Law - Centre for Business in Society - Coventry University. Coventry - Reino Unido. E-mail: kauffmam@coventry.ac.uk.

*** Lawyer, Professor of Higher Education. Doctor, Ph.D. degrees from Sunderland University, UK. Professor, Institute for Future Transport and Cities, Coventry University - UK. Coventry - Reino Unido. E-mail: csx240@coventry.ac.uk.

Doctor at the University of Leeds (UK). Professor at Coventry University (UK), School of Strategy and Leadership, in International Business. Visiting Scholar Professor, Master, and Doctor in Law, Unicesumar (BR). Coventry - Reino Unido. E-mail: ac3371@coventry.ac.uk.

Research funding agencies: Next Seti e ICETI. 
em seus direitos da personalidade. Como principais conclusões, os autores descobriram que a grande maioria desses usuários de tecnologia não tem conhecimento do impacto adverso dos termos e condições acordados em seus direitos da personalidade. Além disso, eles também desconhecem o básico de como a tecnologia opera e, portanto, são incapazes de fazer valer seus direitos. A pesquisa é baseada em dados coletados utilizando uma única pesquisa com uma amostra de 500 estudantes de três universidades de três estados brasileiros com uma idade demográfica entre 18 e 40 anos. Este artigo estende a pesquisa anterior sobre o impacto das tecnologias emergentes nos direitos da personalidade e demonstra com dados empíricos que existe um sério risco de erosão desses direitos. Além disso, esta pesquisa fornece uma visão única dos usuários de tecnologias emergentes no mercado emergente brasileiro e do impacto no sistema jurídico brasileiro.

Palavras-chave: Tecnologias disruptivas. Tecnologias vestíveis. Direitos da personalidade. Inovação social. Tecnologia e direito. Mercados emergentes, Brasil.

\section{Introduction}

One of the main ways to determine whether the use of a new technology results in risks to personality rights is to determine the consumers' level of consciousness in regard to the terms and condition associated with the use of these new technologies, all of which have to be agreed upon by the customers themselves (HASSAN; MATHIASSEN; LOWRY, 2019). In this sense, the engagement of the individual is paramount (CLEMENTS; BOYLE, 2018; ANDREAS; NATARIASARI, 2019) on the protection of personal data in the growing new technologies (LINDQVIST, 2018; BRITO, PINOCHET; LOPES; OLIVEIRA, 2018; ZHU; LIN, 2019). This trend of proliferation of connectivity into new wearable technologies increases the risks related to misuse of personal data due to the broad interoperability and connectivity (ROSE; ELDRIDGE; CHAPIN, 2015).

In Brazil, the Brazilian Civil Rights Framework for the Internet, Law 12.965/2014, the Federal Constitution of 1988 and the recent Law 13.709/2018 set the main regulations establishing the key principles for the protection of personal data (KAUFFMAN; SOARES, 2018). In particular, there is a special emphasis on art. 6 , which require the observance of good faith, clear information and use of security measures, including restriction of access to information, and the access to user data can only be granted in case of prior consent from the data holder.

Research has already shown that new technologies pose a challenge to users due to the invisible and ubiquitous aspects that make it even more difficult to understand the consequences of the acceptance of contractual agreements related to the use and access to personal data collected from such devices. Differently from the previous research, this study analyses the degree of knowledge of users regarding the terms and conditions agreed upon by themselves in respect to the use of wearable technology in Brazil in order to assess the potential risks related to the erosion of personality rights, especially in respect to a right to privacy and two more specific data privacy and access data generated in personal devices. Therefore, this study aims at answering the key question of the study, which boils down to determining to what extent the Brazilian uses of these emerging technologies understand the terms and conditions agreed upon in relation to the use of these new technologies and their impact on personality rights.

\subsection{Conceptual background}

Previous research explored some of the key theoretical issues related to data ownership in the context of wearable technology. This research is an extension of that work and will explore some of the concepts presented in this previous research, such as a brief definition of wearable technology (WU; DONG, CHANG; LIAO, 2015) in combination with a fresh look at the definition of personality rights (MALUF, 2018) and the new threats to those rights.

The concept of Wearable Technology can be defined as "the study or practice of inventing, designing, building, or using miniature body-borne computational and sensory devices" (MANN; SOEGAARD; DAM, 2012). These devices can be found in the form of health monitors, watches, mobile applications, glasses, etc. They can also be inserted into the human body itself or into almost any product, thus becoming part 
of us or our products. These wearable devices can be characterised by particular properties (DVORAK, 2007). It is helpful to understand these characteristics and bear them in mind in order to fully appreciate the emanating legal challenges. As such, we provide the following non-exhaustive list, which explores some of the most relevant properties of wearable devices: embedded, personal, always present, life logging, context aware, decision autonomy.

The expansion of the technologies, which enable these new internet services, leads to changes in the way people and organisations interact (LLOYD; FULLAGA; REID, 2016), thus, giving rise to legal ambiguities and original legal problems. Such technologies include cloud computing, big data, the Internet of Things (IoT), artificial intelligence (Al), cryptography, sensors, robots, algorithms and other information related systems. Most of these technologies depend on cloud computing infrastructures to operate at the upper level.

A particular concept known as loT is the key enabler for the connectivity of computing devices. loT embraces a new concept whereby the virtual world of the Internet converges with the everyday world of "things." The idea is to connect people with each other, but also people with organisations and everyday items.

The focal area of interest for this article is Wearable Technology, which has been described by Gartner as having surpassed the "peak of inflated expectations" and is expected to reach the "plateau of productivity" within the next decade. This is yet another step in the field of miniaturization and personalization of technology, which enhances the interaction among people, devices and organisations in a multitude of ways. Due to the increasing number of wearable devices available for mass markets, wearable computing has already gained significant economic importance and will continue to do so in the foreseeable future.

Having explored the key concepts related to wearable technologies, the attention will turn to an examination of the personality rights related to image, honor, privacy and the guarantees related to personal data protection in relation to the use of wearable technologies in order to asses the user's awareness on the potential risk (CLARKE, 2019) of erosion of personality rights in this context.

\subsection{The Brazilian regulations in this field}

In Brazil, the regulations applicable in the case of personal data can be found in the Federal Constitution of 1988 and provide guarantees to citizens in regards to the inviolability of privacy, the confidentiality of correspondence, data and telephone communications, except in cases where there is a judicial order that lifts these rights (SOARES; CARABELLI, 2019). The important right to informational self-determination, which is a constitutional protection provided in art. $5, \mathrm{X}$, of the Magna Carta, should be applied in social relations by virtue of its horizontal application by imposing the principle of maximum effectiveness of fundamental rights (SOARES; KAUFFMAN; SALES, 2019). Furthermore, the Law no. 12.965/2014, known as the Brazilian Civil Rights Framework for the Internet, in its art. 7 ensures users the rights to the use of the Internet in Brazil, amongst these rights, the inviolability of intimacy and privacy, the confidentiality of information flow for Internet communications, as well as the rights to the stored private communications.

A new legislation was approved and entered into force in 2018 in order to provide greater protection to society in the face of such technological transformation, Law 13.709/2018, which regulates data protection.

\subsection{Context}

As technology continues to evolve at an exponentially increasing rate, it transforms our lives and societies with high speed and impacts the relationship between the individual and society, including business and law. The trend of proliferation of new technologies will only increase in a certain number of adopters, as well as in connectivity, enhancing and spreading at exponential rates the use of wearable devices, mobile phones, tablets and personal computers.

Recently, the emerging opportunities for e-business added a new jolt to the emergence of the so-called wearable technology (wearables), a concept that includes features of smartphones, smartwatches, smart bands, fitness bracelets, virtual reality headsets, smart glasses, pedometers, jackets with headphones, a 
backpack with fast charging instrument and mobile internet access, slimming technology regulator chip for body temperature and metabolism (e.g., without physical effort) mobile technology with integrated GPS, smart jackets and even necklaces with some kind of connectivity and, in general, clothing, smart fabrics and accessories (GURSOY; CHI; LU; NUNKOO, 2019), networked with other devices or directly connected to the internet, sending data to software working in the cloud and that returns information to the users.

By considering the impact of these technologies and, more specifically, the issue of social innovation in the face of new technologies (PARK; $\mathrm{KOH}, 2017$ ) and the relationship between new technologies and the impact on personality rights, with legal issues of personal data protection, the discourse in the previous research presents a limitation in inferring just about possible performance and growth of the sector or investigating the effects of an intelligent technology on customers (FOROUDI; GUPTA; SIVARAJAH; BRODERICK, 2018) or on the effects of information technology on corporate social responsibility (MALAQUIAS, MALAQUIAS; HWANG, 2016; PANTANO; GANDINI, 2017), without collecting empirical data from a representative sample of users to validate the theoretical assumptions.

This gap in previous studies presents an opportunity for contribution to the theory in regards to an empirical study that progresses the current understand in regards to the potential effects of wearable technology on personality rights, particulary the potential erosion of these rights in the Brazilian emerging market.

\section{Methodology}

Having considered the novel and exploratory nature of this study, which explores the potential impact of new technologies on the personality rights of users, the researchers selected a qualitative approach based on online questionnaires. Furthermore, the study used an inductive approach in order to achieve a substantial context and use a flexible structure throughout the research process (LAVILLE; DIONNE, 1999; BUFREM; PRATES, 2005; PANTANO; PRIPORAS, 2016).

As such, a survey was conducted in three Brazilian federal states (São Paulo, Rio de Janeiro and Paraná), reaching a pool of 898 students aged 18-40 years. These individuals are mostly users of new mobile and wearable technologies.

The research aimed to determine the level of awareness of the consequences of third party access to data generated by users through their devices. To ensure that this research collected a data set that represents the general population, the researchers had assistance from UFRJ - Federal University of Rio de Janeiro, Uninove - University Ninth of July, São Paulo and Unicesumar - University Center of Maringá, Paraná; three universities in cities with a representative population of new technologies users.

With the support of the above institutions, the researchers initially obtained contact information for 1000 potential respondents. The removal of 102 people later revealed that the registration was incomplete or had conflicting data or invalid email addresses. The remaining 898 contacts were 497 residents from São Paulo, 212 from Rio de Janeiro and 199 from Paraná.

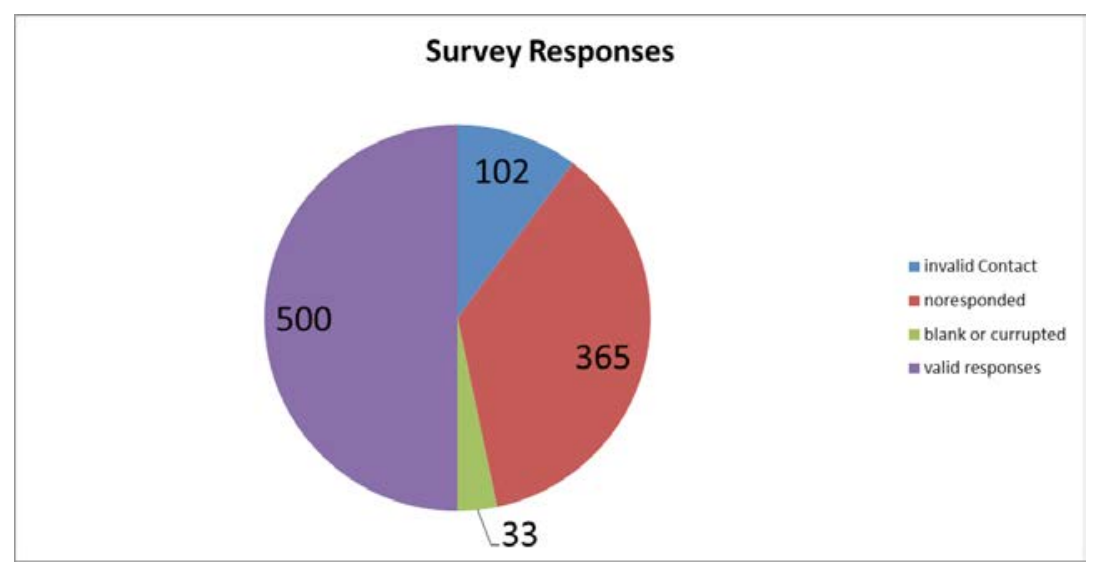


All questionnaires were sent via email with a letter explaining the purpose of the research and the directions of research. The data collection process resulted in 533 responses. Among them, thirty-three electronic responses returned blank or corrupted data and were eliminated. In conclusion, 500 valid responses were received and analysed. The respondents' details were anonymized before analysis to guarantee confidentiality and privacy.

The diagram below shows the survey matrix used to design the questionnaire.

\section{Question - English}

Do you use any form of emerging technology which required an agreement to the collection or access of personal information?

Have you read the terms and conditions associated with the user agreement for the technologies being utilised?

To what extent do you believe that you fully understand the terms and conditions you have agreed to?

To what extent do you understand how your data is stored and who has access to it?

To what extent to you think that this level of access to you personal information can affect you personality rights?

\section{i. Sample Selection}

The sample consisted mainly of students from the abovementioned supporting institutions. As such, the researchers acknowledge that this is in fact a "convenience" sampling, as described by (RITCHIE; LEWIS; NICHOLLS; ORMSTON, 2013). Participants were recruited on the basis of their availability to participate in the study. The age range between 18 and 40 was purposively selected in order to improve the likelihood of the participants of having familiarity with the new technologies subject to this study.

The following xyz table shows the proportion of male and female respondents, as well as the age group spread.

\begin{tabular}{|c|c|c|c|c|c|}
\hline Sexo & $\#$ & $\%$ & Age & $\#$ & $\%$ \\
\hline $\mathbf{M}$ & 190 & 0.38 & 18 & 17 & 0.034 \\
\hline \multirow[t]{23}{*}{$F$} & 310 & 0.62 & 19 & 32 & 0.064 \\
\hline & & 1 & 20 & 36 & 0.072 \\
\hline & & & 21 & 33 & 0.066 \\
\hline & & & 22 & 36 & 0.072 \\
\hline & & & 23 & 31 & 0.062 \\
\hline & & & 24 & 32 & 0.064 \\
\hline & & & 25 & 24 & 0.048 \\
\hline & & & 26 & 24 & 0.048 \\
\hline & & & 27 & 20 & 0.04 \\
\hline & & & 28 & 24 & 0.048 \\
\hline & & & 29 & 15 & 0.03 \\
\hline & & & 30 & 25 & 0.05 \\
\hline & & & 31 & 20 & 0.04 \\
\hline & & & 32 & 20 & 0.04 \\
\hline & & & 33 & 20 & 0.04 \\
\hline & & & 34 & 21 & 0.042 \\
\hline & & & 35 & 17 & 0.034 \\
\hline & & & 36 & 16 & 0.032 \\
\hline & & & 37 & 12 & 0.024 \\
\hline & & & 38 & 10 & 0.02 \\
\hline & & & 39 & 8 & 0.016 \\
\hline & & & 40 & 7 & 0.014 \\
\hline & & & & 500 & 1 \\
\hline
\end{tabular}




\section{Results}

As mentioned in the previous section, 500 valid responses from users of wearable technologies were collected. The obtained responses are disclosed in the graph below.

Therefore, 500 responses were received and considered valid, but subsequently 65 responses were eliminated as the respondents indicated that they were not users of new technologies, which are the object of this study.

As such, 435 responses were valid for data analysis, and the successful response rate was $43.5 \%$ of the total potential respondents and $87 \%$ of the valid responses.

\begin{tabular}{|c|c|c|c|}
\hline \multirow{4}{*}{ Q1 } & Answer & $\#$ & $\%$ \\
\hline & 1 & 435 & 0.87 \\
\hline & 2 & 65 & 0.13 \\
\hline & & 500 & 1 \\
\hline
\end{tabular}

From the 435 responses, when asked, "Have you read the terms and conditions associated with the user agreement for the technologies being used?", there were 116 positive responses and 319 negative responses, representing $73 \%$ of the valid responses.

\begin{tabular}{|c|c|cc|}
\hline \multirow{3}{*}{ Q2 } & Answer & $\#$ & $\%$ \\
\cline { 2 - 4 } & 1 & 116 & 0.266667 \\
& 2 & 319 & 0.733333 \\
\cline { 3 - 4 } & & $\mathbf{4 3 5}$ & $\mathbf{1}$ \\
\cline { 3 - 4 } & & &
\end{tabular}

Furthermore, when asked "To what extent do you believe that you fully understand the terms and conditions you have agreed to?", 85 users responded that they do understand and 82 have indicated that they understand well. Therefore, the data shows a high rate of unawareness with 102 answers for "do not understand", 125 "somewhat understand" and; only 41 responses indicated that users "fully understand" the terms and conditions accepted, representing $9.42 \%$.

\begin{tabular}{|c|c|cc|} 
& Answer & $\#$ & \% \\
\hline \multirow{4}{*}{ Q3 } & 1 & 102 & 0.234483 \\
& 2 & 125 & 0.287356 \\
& 3 & 85 & 0.195402 \\
& 4 & 82 & 0.188506 \\
& 5 & 41 & 0.094253 \\
\hline & & $\mathbf{4 3 5}$ & $\mathbf{1}$ \\
\hline
\end{tabular}

The fourth question, "To what extent do you understand how your data is stored and who has access to it?", resulted in 89 users that responded that they understand and 88 understand well, with 91 that do not understand and 112 that somewhat understand. Finally, only 55 respondents indicated that they fully understand how their data is stored and who has access to it.

\begin{tabular}{|l|c|c|c|}
\hline \multirow{4}{*}{ Q4 } & Answer & $\#$ & $\%$ \\
\hline \multirow{4}{*}{} & 1 & 91 & 0.209195 \\
& 2 & 112 & 0.257471 \\
& 3 & 89 & 0.204598 \\
& 4 & 88 & 0.202299 \\
& 5 & 55 & 0.126437 \\
\hline & & $\mathbf{4 3 5}$ & $\mathbf{1}$ \\
\hline
\end{tabular}

Finally, in the fifth and last question, "To what extent to you think that this level of access to your personal information can affect your personality rights?", 102 users indicated they believe that their personality rights will be affected, and 73 respondents indicated that their personality rights will be negatively affected, compared to 79 respondents that believe that their personality rights will not be affected, and 101 that believe that their personality rights will only be slightly affected. Finally, 80 respondents indicated that they believe that their personality rights will be negatively affected by the new technologies. 


\begin{tabular}{|c|c|cc}
\multirow{4}{*}{ Q5 } & Answer & $\#$ & $\%$ \\
& 1 & 79 & 0.181609 \\
& 2 & 101 & 0.232184 \\
& 3 & 102 & 0.234483 \\
& 4 & 73 & 0.167816 \\
& 5 & 80 & 0.183908 \\
\hline & & $\mathbf{4 3 5}$ & $\mathbf{1}$ \\
\hline
\end{tabular}

These results indicate at least a level of vulnerability from users due to the lack of understanding regarding the terms and conditions associated with the use of the new wearable technologies and the potential consequences in relation to their personality rights.

The following table summarises the survey questions and results.

\begin{tabular}{|c|c|c|c|c|c|}
\hline \multirow{2}{*}{ Question - English } & \multicolumn{5}{|c|}{ Responses } \\
\hline & 1 & 2 & 3 & 4 & 5 \\
\hline $\begin{array}{l}\text { Do you use any form of emerging technology which required an agreement to } \\
\text { the collection or access of personal information? }\end{array}$ & Yes & No & & & \\
\hline $\begin{array}{rr} & \text { Results } \\
\end{array}$ & 435 & 65 & & & \\
\hline $\begin{array}{l}\text { Have you read the terms and conditions associated with the user agreement } \\
\text { for the technologies being utilised? }\end{array}$ & Yes & No & & & \\
\hline $\begin{array}{rr} & \text { Results } \\
\end{array}$ & 116 & 319 & & & \\
\hline $\begin{array}{l}\text { To what extent do you believe that you fully understand the terms and } \\
\text { conditions you have agreed to? }\end{array}$ & $\begin{array}{c}\text { Do not } \\
\text { understand }\end{array}$ & $\begin{array}{l}\text { Somewhat } \\
\text { understand }\end{array}$ & Understand & Understand well & Fully Understand \\
\hline $\begin{array}{rr} & \text { Resutts } \\
\end{array}$ & 102 & 125 & 85 & 82 & 41 \\
\hline $\begin{array}{l}\text { To what extent do you understand how your data is stored and who has } \\
\text { access to it? }\end{array}$ & $\begin{array}{c}\text { Do not } \\
\text { understand }\end{array}$ & $\begin{array}{l}\text { Somewhat } \\
\text { understand }\end{array}$ & Understand & Understand well & Fully Understand \\
\hline $\begin{array}{rr} & \text { Resutts } \\
\end{array}$ & 91 & 112 & 89 & \begin{tabular}{l|l}
88 \\
\end{tabular} & 55 \\
\hline $\begin{array}{l}\text { To what extent to you think that this level of access to you personal } \\
\text { information can affect you personality rights? }\end{array}$ & Will not affect & Will affect slightly & Will affect & $\begin{array}{l}\text { Is likely that will } \\
\text { affect negatively }\end{array}$ & $\begin{array}{l}\text { Will affect } \\
\text { negatively }\end{array}$ \\
\hline Results & 79 & 101 & 102 & 73 & 80 \\
\hline
\end{tabular}

Having explored the results, attention now will turn to the discussion regarding the implications of these results.

\section{Discussion}

The occurrence of digital incidents with users' personal information may have two main sources: external factors (such as rack attacks or leak of data to third parties) and/or internal reasons (when the user himself leaves the personal data vulnerable, their data having released access to third parties before the agreement to the terms and conditions, whose access to that information starts to be improper or illegal uses, the formulation of a clandestine database). The latter occurrence is of interest to this study, vulnerabilities from corporis internal cause, especially in the formation of a database, ab initio, authorized by consumers, but unauthorized in the allocation of the data, for violation and transgression of protection rules data and objective good faith that must permeate each and every relationship with the consumer.

The data analysis revealed vulnerabilities and also a perceived erosion of personality rights. When $73 \%$ of the responses point to a total lack knowledge of the said terms and conditions; it is concluded that $41.37 \%$ do not realize or realize a little impact to personality rights regarding the access of personal information collected from wearable technologies by third parties. The uses give access to personal data, without regard to the allocation of such data. Thus, there is a clear and real opportunity for misuse of personal data.

This is evident when the answers to the second question showed that of 435 respondents who use wearable technologies, 319 said they do not read the terms and conditions associated with the products using "the wearable technologies". This demonstrates a level of vulnerability that exceeds two thirds of the respondents at $73 \%$ of users in the studied group.

Furthermore, the third question confirms these findings as for those who do not read, may not have realized and understood the scope of the terms and conditions. Thus, this supports the conclusion of vulnerability and the high risk of erosion of personality rights, especially the right to privacy and data privacy. The third question also showed that only 41 respondents fully understand the terms and conditions, equivalent to $9.42 \%$. 
This response suggests that more than $90 \%$ are exposed to some kind of risk related to leakage of data and personal information in relation to the use of the new wearable technologies.

In addition, the data analysis has also demonstrated a high degree of ignorance on how personal data generated and captured through wearable device is stored and who has access to it. In the fourth question, the answers "no" or "little knowledge" included 203 users, a number equivalent to more than $45 \%$, given that only 55 reported having full knowledge, equivalent to less than $13 \%$; then really up the high-risk vulnerability of personality rights involved. This risk is proven for that analysed sample.

In the last question, the level of access to information with vulnerability to the protection of involved personality rights was demonstrated, as the users answered assertively and categorically, in an equally high proportion, and the answers "no" or "little understanding" were presented by 180 users, more than $46 \%$, and 80 answered have full knowledge, equivalent to less than $19 \%$.

In summary, there were five specific questions, which demonstrated the vulnerabilities of consumer data in wearable technologies. The exact extent to which consumers or wearable technologies users are opening their personal data and signing up to terms and conditions which they do not understand. Consequently, companies that have access to this data can do several things, which may lead to a potential adverse impact on the users personality rights and result in an invasion of their rights to image, honor and privacy, the so far inviolable rights of the consumer-user.

For example, when releasing the buying habits or search history regarding potential purchases, the consumer is vulnerable to systematic attacks of advertisements, and this, unfortunately, has become common practice. And there are specific cases showing that such actions are almost instantaneous, as if the wearable technology device detected a message exchange on a vehicle accident, in real time, offering the location, it can go search the history of user's accidents to influence the calculation of the premium for the next insurance contract, which considers the risk of accidents for a particular user.

In the same area of insurance, now as life insurance, when the insurance company gets information that particular tenderer is common in typical bars of alcoholics by location history or the analysis of heart rate of a particular user, with inside information on changes frequency in the idle state, in knowing the increased risk of a heart attack, for example, the calculation of changes, raising the price of the insurance contract, and may also determine the refusal of employment. In another collection, in politics, in elections, certain polititians check the rejection of their church or cult supporters and thus have access to the wearable devices of these individuals; they can begin to send messages regarding meeting attendance of such a church and that the political user who sympathizes with aligned religious causes.

Similar application in fake news has already been used in the elections in the USA. Still, the location in real time, if used by third parties can be extremely harmful to the consumer, since approaches to sales or services in person, when you do cross-checks with the habits of where they attend and consume; as their location in unwanted situations, such as in a forensic service by default in vexatious charges, as the location tracking by suspicious husbands or boyfriends, submitting explanations that would be unnecessary.

In this study, we have introduced the main rights subject to erosion in the context of personality rights; the objectivist and subjectivist theory of accountability for that unduly use of personal data; third party liability to acquire or access the data; severance quantification value; and, de lege ferenda, indicating improvements in the legal system.

In this context, first, it is clear that users and consumers, in a globalized economy, from both Federal State Capitals, characterised by greater dynamism, and countryside cities, are more likely to experience external pressures in order to quickly take consumption that did not exist in a volatile environment, marked by the quick advance of new technologies in any region, even in the most inhospitable ones.

The study demonstrated that the vast majority of technology users that took part in the survey are not aware of the negative impact of the terms and conditions agreed upon on personality rights. In addition, they are also not aware of the basics of how technology works and, therefore, are unable to assert their rights. 


\subsection{Erosion of personality rights, civil accountability in the objectivist and subjectivist theory and the indemnity quantification}

Firstly, this study collected new data by identifying and demonstrating the vulnerability and erosion of personality rights, from the unrestrained access to personal data in wearable technologies, often with the consent of the user before the full lack of a significant portion of Brazilian population on the terms and conditions associated with the consumer's agreement to use these technologies.

The study collected data to demonstrate the perceptions of consumers; and the adequacy of these measures has been empirically examined. These measures can facilitate empirical research efforts on the perceptions of consumers to achieve greater security in the use of wearable technology in future research. It can be open to new regulations, such as stricter ones, for example, requiring that every advertising media also warns consumers on the risks to authorize the opening of their data or simply authorize access to their location.

Secondly, this study identifies the role of external pressures and maturity in driving consumer perceptions and business strategies access to personal data from the use of wearable technology. It is suggested that the business has the least critical ability to work safely for consumers, a typical organization and own the entrepreneurs (KOR; MAHONEY; MICHAEL, 2007; GRÉGOIRE; SHEPHERD, 2012; SIEGEL; RENKO, 2012).

However, little empirical effort was made to support this statement. Our research suggests a strong psychological pressure on consumers, who want the product, and the business requires accepting the terms and conditions before accessing the product with sealed packages (DIMAGGIO; POWELL, 1983; TEO; POK, 2003; SEURING; MÜLLER, 2008).

The use of standard terms and conditions cannot supplant and relegate the security of data processing and personal information opportunities. The findings of the driving forces contributes to the literature of strategic management (MALAQUIAS; MALAQUIAS; HWANG, 2016; KIM; HEBELER; YOON; DAVIS, 2018), secure innovation and multidisciplinary studies with the law.

Alongside the criminal sphere, this article analyzes the implications under civil law and civil procedure, under the indemnity perspective and accountability of legitimacy. So, it is subject to analysis in three dimensions of accountability to those who access the data: a zero accountability that it operates within the law, with due diligence and security; the objective accountability simply because of evidence of unauthorized access to personal data; and finally, the subjective responsibility, which requires proof of damage and guilt in the unauthorized access of personal data.

In addition, when the access to available data on payment services passes from the collector agent to third parties, there may be a risk that third party is receiving stolen data. Still, we also have a concern with indemnity quantification, that is, there is an infringement of the right to image or honor, damaging the right to privacy and intimacy, which is the indemnity amount that the courts have sentenced to those who have improperly accessed the personal data of wearable technologies users.

Finally, our results show that the two driving forces in our study, the lack of definitions of the terms and conditions of access to personal data for many of the Brazilian consumers and the high lack of allocation of data collected from personal devices in new wearable technologies, eventually result in erosion of personality rights. These results suggest the civil liability of unauthorized access by entrepreneurs and service providers, with different levels, depending on the way that data protection is accessed and securing that data.

In addition, there were convictions in the Supreme Court of Justice, the unauthorized access to personal data that, incidentally, has already expressed an understanding for protecting the rights to privacy and private life, directly related to the use of personal data in databases, in the consecration of the right to self-determination informative (STJ - EDCI in REsp 1630659/DF, tried on 11/27/2018). Not even the Judiciary may violate the right to data protection, and the disclosure of information is one exception, only occasionally used when necessary, in the face of public policy (STJ - Habeas Corpus 479053/SP, judged 05/28/2019). In a recent case, the Supreme Court recognized that the compensation for harm to the child image conveyed without the permission of the legal representative is in re ipsa, i.e. the result of strict liability, 
and set compensation of around US $\$ 10,000$ for each individual who suffered moral damages (STJ - Resp 1628700/MG, judged on 02/20/2018) and, once the subjective guilt is recognized, it is also still subject, the offender, to pay for damages that are proven.

This result suggests that partners, service providers, users, entrepreneurs and competitors strive to understand the protective legislation, including under the given objective good faith by understanding the different impacts and maturity of business planning in the face of events.

This study suggests that entrepreneurs should explore the safety improvements in access to personal data, including contract employees, to maintain the levels of protection to the consumer and minimize the risks of doing business.

\subsection{Notes de Lege Ferenda}

In order to provide greater security to the population, Law 13.709/2018 entered into force in Brazil, which regulates data protection. In order to improve the legislated system, de lege ferenda, it suggests to include in the legal text that companies are required, in tow advertising and business calls, the new wearable technologies with warnings about the risks and/or recommendations for personal data protection, in fine of penalty.

\subsection{Practical Implications}

Our study has two important implications for business practice. First, our study provides decision-making elements for business owners understand the need to provide greater security in the processing of information received from consumers directly from their wearable technology devices. Second, entrepreneurs have, here, a sense of indemnity as they can get access to and misuse such information. Our findings go in encouraging good business practices, which start with good planning and experience of past operational experience and have not been successful. The improvement is needed and continuous, it is what we encourage.

\section{Conclusion}

Despite revolutionary changes that bring wearable technology (DEKLEVA, 2004; TANG, 2014), given the fact that there is a serious risk of erosion of such rights, it is necessary to understand the behavior of standard consumer, to develop a protection with good business practices and bring about necessary changes in the traditional economy (PARK; JAYARAMAN, 2003; GAO; LI; LUO, 2015; JACOBS et al., 2019). In this study, we introduce the theory of the entrepreneurial responsibility in the research context, into three dimensions of accountability to those who access the personal data in wearable technologies: zero accountability that it operates within the law, with due diligence and security; the objective accountability simply because of evidence of unauthorized access to personal data; and finally, the subjective responsibility, which requires proof of fault and damages the unauthorized access of personal data. That comes to crown and encourage the unique role of the good market business practices.

\section{References}

ANDREAS, Andreas; NATARIASARI, Riska. Satisfaction ERP Systems: Impact on End-User. Indonesian Journal of Economics, Social, and Humanities, v. 1, p. 59-63, 2019.

BRAZIL. Superior Tribunal de Justiça. EDcl no REsp 1630659/DF. Rel. Nancy Andrighi, Terceira Turma, julgado em 27/11/2018. DJe 06 dez. 2018.

BRAZIL. Superior Tribunal de Justiça. HC 479053/SP. Rel. Ribeiro Dantas, Quinta Turma, julgado em 28/05/2019. DJe 04 jun. 2019.

BRAZIL. Superior Tribunal de Justiça. REsp 1628700/MG. Rel. Ricardo Villas Bôas Cueva, Terceira Turma, julgado em 20/02/2018. DJe 01 mar. 2018. 
BRITO, Richard D'arc da Silva; PINOCHET, Luis Hernan Contreras; LOPES, Evandro Luiz; OLIVEIRA, Mauri Aparecido de. Desenvolvimento de uma escala de mensuração de características de gamificação para usuários de aplicativos em dispositivos móveis. Internext, v. 13, p. 1-16, 2018.

BUFREM, Leilah; PRATES, Yara. O saber científico registrado e as práticas de mensuração da informação. Ciência da Informação, v. 34, s. 2, p. 9-25, 2005.

CLARKE, Roger. Risks inherent in the digital surveillance economy: A research agenda. Journal of Information Technology, v. 34, n. 1, p. 59-80, 2019.

CLEMENTS, Jeffrey A.; BOYLE, Randall. Compulsive technology use: Compulsive use of mobile applications. Computers in Human Behavior, v. 87, p. 34-48, 2018.

DEKLEVA, Sasha. M-Business: Economy Driver or a Mess? Communications of the Association for Information Systems, v. 13, n. 11, 2004.

DIMAGGIO, Paul J.; POWELL, Walter W. The iron cage revisited: Institutional isomorphism and collective rationality in organizational fields. American sociological review, p. 147-160, 1983.

DVORAK, Joseph L. Moving wearables into the mainstream: Taming the Borg. Springer Science \& Business Media, 2007.

FOROUDI, Pantea; GUPTA, Suraksha; SIVARAJAH, Uthayasankar; BRODERICK, Amanda. Investigating the effects of smart technology on customer dynamics and customer experience. Computers in Human Behavior, v. 80, p. 271-282, 2018.

GAO, Yiwen; LI, He; LUO, Yan. An empirical study of wearable technology acceptance in healthcare. Industrial Management \& Data Systems, v. 115, s. 9, p. 1704-1723, 2015.

GRÉGOIRE, Denis A.; SHEPHERD, Dean A. Technology-market combinations and the identification of entrepreneurial opportunities: An investigation of the opportunity-individual nexus. Academy of Management Journal, v. 55, n. 4, p. 753-785, 2012.

GURSOY, Dogan; CHI, Oscar Hengxuan; LU, Lu; NUNKOO, Robin. Consumers acceptance of artificially intelligent (Al) device use in service delivery. International Journal of Information Management, v. 49, p. 157-169, 2019.

HASSAN, Nik Rushdi; MATHIASSEN, Lars; LOWRY, Paul Benjamin. The process of information systems theorizing as a discursive practice. Journal of Information Technology, v. 34, n. 3, p. 198-220, 2019.

JACOBS, Jesse V.; HETTINGER, Lawrence J.; HUANG, Yueng-Hsiang; JEFFRIES, Susan; LESCH, Mary F.; SIMMONS, Lucinda A., VERMA, Santosh K.; WILLETTS, Joanna L. Employee acceptance of wearable technology in the workplace. Applied ergonomics, v. 78, p. 148-156, 2019.

KAUFFMAN, Marcos Eduardo; SOARES, Marcelo Negri. New Technologies and Data Ownership: Wearables and the Erosion of Personality Rights. Revista Direitos Sociais e Políticas Públicas UNIFAFIBE, v. 6, n. 1, p. 512-538, 2018.

KIM, Dan Jorgensens; HEBELER, John; YOON, Victoria; DAVIS, Fred. Exploring Determinants of Semantic Web Technology Adoption from IT Professionals' Perspective: Industry Competition, Organization Innovativeness, and Data Management Capability. Computers in Human Behavior, v. 86, p. 18-33, 2018.

KOR, Yasemin Y.; MAHONEY, Joseph T.; MICHAEL, Steven C. Resources, capabilities and entrepreneurial perceptions. Journal of Management Studies, v. 44, n.7, p. 1187-1212, 2007.

LAVILLE, Christian; DIONNE, Jean. A construção do saber: manual de metodologia da pesquisa em ciências humanas. Porto Alegre: Artmed; Belo Horizonte: UFMG, 1999.

LINDQVIST, Jenna. New challenges to personal data processing agreements: is the GDPR fit to deal with contract, accountability and liability in a world of the Internet of Things? International Journal of Law and Information Technology, v. 26, n. 1, p. 45-63, 2018. 
LLOYD, Kathy; FULLAGAR, Simone; REID, Sacha. Where is the 'social' in constructions of 'liveability'? Exploring community, social interaction and social cohesion in changing urban environments. Urban Policy and Research, v. 34, n.4, p. 343-355, 2016.

MALAQUIAS, Rodrigo Fernandes; MALAQUIAS, Fernanda Francielle de Oliveira; HWANG, Yujong. Effects of information technology on corporate social responsibility: Empirical evidence from an emerging economy. Computers in Human Behavior, v. 59, p. 195-201, 2016.

MALUF, Carlos Alberto Dabus. Introdução ao direito civil. 2. ed. São Paulo: Saraiva, 2018.

MANN, Steve; SOEGAARD, Mads; DAM, Rikke Friis. Wearable Computing, in: The encyclopedia of human-computer interaction. Aarhus, Denmark: The Interaction-design. Org foundation, 2. ed. 2012.

PANTANO, Eleonora; GANDINI, Alessandro. Exploring the forms of sociality mediated by innovative technologies in retail settings. Computers in Human Behavior, v. 77, p. 367-373, 2017.

PANTANO, Eleonora; PRIPORAS, Constantinos-Vasilios. The effect of mobile retailing on consumers purchasing experiences: A dynamic perspective. Computers in Human Behavior, v. 61, p. 548-555, 2016.

PARK, Kyungja; $\mathrm{KOH}$, Joon. Exploring the relationship between perceived pace of technology change and adoption resistance to convergence products. Computers in Human Behavior, v. 69, p. 142-150, 2017.

PARK, Sungmee; JAYARAMAN, Sundaresan. Enhancing the quality of life through wearable technology. IEEE Engineering in medicine and biology magazine, v. 22, n. 3, p. 41-48, 2003.

RITCHIE, Jane; LEWIS, Jane; NICHOLLS, Carol McNaughton; ORMSTON, Rachel. Qualitative research practice: A guide for social science students and researchers. London: Sage. 2013.

ROSE, Karen; ELDRIDGE, Scott; CHAPIN, Lyman. The internet of things: An overview. The Internet Society (ISOC): Carolyn Marsan, v. 1, 2015.

SEURING, Stefan; MÜLLER, Martin. From a literature review to a conceptual framework for sustainable supply chain management. Journal of Cleaner Production, v. 16, p. 1699-1710, 2008.

SIEGEL, Donald S.; RENKO, Maija. The role of market and technological knowledge in recognizing entrepreneurial opportunities. Management Decision, v. 50, n. 5, p. 797-816, 2012.

SOARES, Marcelo Negri; KAUFFMAN, Marcos Eduardo; SALES, Gabriel Mendes de Catunda. Avanços da Comunidade Europeia no Direito de Propriedade Intelectual e Indústria 4.0: Extraterritorialidade e Aplicabilidade do Direito Comparado no Brasil. Revista do Direito (Santa Cruz do Sul. Online), v. 1, n. 57, p. 117-137, jan./abr. 2019.

SOARES, Marcelo Negri; CARABELLI, Thaís Andressa. Constituição, devido processo legal e coisa julgada no processo civil. 2. ed. São Paulo: Blucher, 2019. v. 1.

TANG, Waterloo Yu. Mobile wireless communications device providing security features based upon wearable near field communication (nfc) device and related methods. U.S. Patent Application $\mathbf{n}$.

13/648,576, 10 abr. 2014.

TEO, Thompson; POK, Siau Heong. Adoption of WAP-enabled mobile phones among Internet users. Omega, v. 31, n. 6, p. 483-498, 2003.

WU, Yen-Chun Jim; DONG, Tse-Ping; CHANG, Chan-Lan; LIAO, Ya-Chun. A collaborative learning lesson from using effective information technology combinations. Computers in Human Behavior, v. 51, Part B, p. 986-993, Oct. 2015.

ZHU, Zhen; LIN, Shuai-fu. Understanding entrepreneurial perceptions in the pursuit of emerging e-business opportunities: The dimensions and drivers. Computers in Human Behavior, v. 95, p. 252261, 2019.

Recebido em: 16/09/2019

Aprovado em: 26/03/2020 